International Business and Global Economy 2017, no. 36, pp. 248-261

Biznes międzynarodowy w gospodarce globalnej 2017, nr 36, s. 248-261

Edited by the Institute of International Business, University of Gdańsk

ISSN 2300-6102

e-ISSN 2353-9496

DOI 10.4467/23539496IB.17.017.7465

Taner Sigindi

Muğla Sttkı Koçman University

\title{
Satisfaction and dimensions of loyalty in B2B markets: A study among the users of electronic security services
}

The purpose of the study is to provide an understanding of how customer satisfaction affects dimensions of loyalty in the B2B service industry. In this regard, the effect of satisfaction on attitudinal loyalty, behavioural loyalty, price tolerance, complaining behaviour, word-of-mouth marketing, and behavioural intention was explored in the Turkish B2B markets. The hypotheses of the study were tested through a survey conducted in small and medium-sized businesses operating in the electronic security sector. In the analysis of the collected data, explorative factor analysis and simple linear regression were run. According to the findings, the effect of customer satisfaction on the dimensions of loyalty can be presented in descending order as follows: behavioural intention, word-of-mouth marketing, attitudinal loyalty, price tolerance, behavioural loyalty. No significant relationship was found between satisfaction and complaining behaviour. This study is expected to highlight the influence of customer satisfaction on various loyalty dimensions in the B2B service industry in Turkey.

Keywords: customer loyalty, customer satisfaction, B2B, services, electronic security

JEL classification: M310

\section{Satysfakcja i wymiary lojalności na rynkach B2B - badanie wśród nabywców usług z zakresu bezpieczeństwa elektronicznego}

Celem niniejszego artykułu jest wyjaśnienie wpływu satysfakcji klienta na różne wymiary lojalności na rynku usług B2B. Badaniu poddano wpływ satysfakcji na lojalność jako postawę, zachowanie, roszczeniowość, marketing szeptany oraz intencję behawioralną na tureckich rynkach B2B. Sformułowane hipotezy zweryfikowano na podstawie wyników badań przeprowadzonych wśród małych i średnich firm działających w sektorze bezpieczeństwa elektronicznego. Zebrane dane poddano eksploracyjnej analizie czynnikowej oraz prostej regresji liniowej. Z rezultatów badań wynika, że wpływ satysfakcji klienta na stopień lojalności można ukazać w następującym porządku malejącym: intencja behawioralna, marketing szeptany, postawa, tolerancja cenowa, zachowanie. Stwierdzono brak istotnego związku pomiędzy satysfakcją a roszczeniowością. Oczekuje się, iż praca ta uwypukli wpływ satysfakcji klienta na różne wymiary lojalności na rynku usług B2B w Turcji.

Słowa kluczowe: lojalność klienta, satysfakcja klienta, B2B, usługi, bezpieczeństwo elektroniczne

Klasyfikacja JEL: M310 


\section{Introduction}

The fact that gaining new customers is a more expensive process than retaining current customers [Reichheld, 1993; 1996] has increased the businesses' desire to keep their current customers. In recent years this has naturally led to an intense discussion of the concept of loyalty in the field of marketing [Hyun, 2010; McMullan, 2005; Rundle-Thiele, 2005]. While some research in the literature [e.g. Grönholdt, Martensen, Kristensen, 2000; Hyun, 2010; Özdemir, Koçak, 2012] attempted to determine the antecedents of customer loyalty, other research [Rundle-Thiele, Mackay, 2001; Rundle-Thiele, 2005] focused on determining the dimensions of loyalty and measuring consumer loyalty levels.

Various studies [Fiol et al., 2009; Martín-Consuegra, Molina, Esteban, 2007] reveal that customer satisfaction is an important variable affecting loyalty. On the other hand, it has been argued that such variables as service quality, perceived value, and trust affect customer loyalty as well [Fiol et al., 2009; Grönholdt, Martensen, Kristensen, 2000; Auh, Shih, 2005]. Although there is a large number of studies investigating the relationship between customer satisfaction and loyalty, it can be maintained that they examine only a single or limited dimensions of loyalty [Auh, Shih, 2005; Lai, 2015]. In recent years, however, it has been widely commented that evaluation of loyalty on the basis of a single or few dimensions is quite inadequate and that this concept should be addressed multi-dimensionally [see Bloemer, Ruyter, Wetzels, 1999; Rundle-Thiele, 2005]. In these studies, different sub-dimensions of the concept of loyalty - such as attitudinal loyalty, loyalty tendency, behavioural loyalty, complaining, resistance to rival suggestions, behavioural intention, and price acceptance - were distinguished.

On the other hand, studies addressing the relationship between satisfaction and loyalty focused mainly on goods [Fiol et al., 2009] or applications intended for consumer market [Bougie, Pieters, Zeelenberg, 2003; Sanchez, Vijande, Gutierrez, 2012]. In particular, it is thought that the relationship between customer satisfaction and the dimensions of loyalty in relation to service goods in the B2B market has not been adequately addressed. Thus, the purpose of the current study is to examine the relationship between satisfaction and the dimensions of loyalty in the B2B service industry. To this end, the relationship between customer satisfaction and attitudinal loyalty, behavioural loyalty, behavioural intention, complaining, word-of-mouth, and price tolerance was investigated.

In the following section, after the explanation of the key concepts used in the study, the relationships between customer satisfaction and the dimensions of loyalty are explored. Then, an empirical study conducted to investigate these relationships in the organisational service market is presented. In the last part, in light 
of the findings, the results of the study are discussed, limitations explained, and suggestions made for further research.

\section{Key concepts}

First, the key concepts used in the current study will be explained. In this section, the evolution and the scope of the concepts of satisfaction and loyalty in the literature will be discussed.

\subsection{Satisfaction}

Customer satisfaction is one of the most essential elements holding the potential of increasing company profit by affecting loyalty [Homburg, Koschate, Hoyer, 2005; Kim, Vogt, Knutson, 2015]. The expectation disconfirmation theory developed by Oliver [1980] seems to be the most widely used in the literature to explain this concept. According to this theory, customers compare their expectations regarding a product with its actual performance. Depending on whether the performance exceeds the expectations or not, customer satisfaction increases or decreases (or, to put it differently, dissatisfaction increases) [Mattila, Wirtz, 2000; Wirtz, Mattila, Tan, 2000]. Recent studies, which explore cognitive and affective dimensions of satisfaction, take under consideration the emotions of customers as well [Kim, Vogt, Knutson, 2015].

The concept of satisfaction in the business market has been investigated by many researchers [Brennan, Turnbull, Wilson, 2003; Nijssen et al., 2003]. According to Frazier, Gill, and Kale [1989], it has two dimensions: an economic one and a social one, and is related to the establishment of business partners with the purpose of creating competitive advantage. In general, satisfaction in the business market is viewed to be an affective state arising from all business relationships [Fiol et al., 2009; Spreng, Shi, Page, 2009]. Due to the intangibility of services, the effect of satisfaction on loyalty is greater in the case of services than goods. Particularly when considering goods for which brand choice is of great importance, attitude is the main element affecting loyalty [Lee, Bellman, 2008]. In their study of industrial suppliers and producers, Eggert and Ulaga [2002] treated attitude as one-dimensional and found that perceived value affects attitude and attitude affects loyalty. In the current study, attitude was also considered along a single dimension. 


\subsection{Loyalty}

There is no commonly agreed understanding of the concept of loyalty in the literature [Bloemer, Ruyter, Wetzels, 1999]. The reason for this can be the evolution of its dimensions. The concept of loyalty was treated as a unidimensional construct when it was first introduced in the 1940s; in the following period it began to be considered as comprising two dimensions: attitudinal and behavioural [Rundle-Thiele, 2005]. This bi-dimensional approach, also known as mixed-loyalty approach [Özdemir, Koçak, 2012], examines consumer behaviour and attitude towards products or brands [Amine, 1998; Bennett, Härtel, McColl-Kennedy, 2005]. Although different researchers still adopt a mixed-loyalty approach [RundleThiele, Mackay, 2001; Yi, La, 2004], the number of studies examining loyalty as multi-dimensional is increasing [Zeithaml, Berry, Parasuraman, 1996; RundleThiele, 2005]. In addition to addressing the behavioural and attitudinal dimensions, these studies also conceptualised such dimensions as complaining behaviour, behavioural intention, resistance to rival products or brands, and loyalty tendency [Rundle-Thiele, 2005; Rundle-Thiele, Mackay, 2001].

One of the first studies addressing loyalty as a multi-dimensional construct was conducted by Oliver [1997], who attempted to explain loyalty by adopting a developmental process approach and maintained that there are four levels of loyalty of varied strengths. The weakest level is cognitive loyalty, which is manifested when the consumer cares more about the costs and benefits of a product than about a brand itself. The second level - affective loyalty - is based on the attitude of the consumer and his satisfaction with a product or a brand. The third level - conative loyalty - refers to a behavioural intention to repurchase and involves a profound devotion to a brand. At the last and strongest level - action loyalty - attitude is converted into action. The costumer is ready to make an effort to reach the desired brand.

In their study investigating the effect of service quality on loyalty, Bloemer, Ruyter, and Wetzels [1999] dealt with four dimensions of loyalty: word-of-mouth, purchasing intention, price tolerance, and complaining. On the other hand, the European Customer Satisfaction Index (ECSI), developed and widely used in the literature to evaluate satisfaction and loyalty levels of European customers, measures loyalty by using dimensions such as repurchasing intention, desire to purchase another product from the same brand, price tolerance, and recommending a product or a brand to other customers [Grönholdt, Martensen, Kristensen, 2000].

Kim, Vogt, and Knutson [2015] developed three models of the effect of satisfaction and delight on the cognitive, affective, and intentional dimensions of loyalty. In two of the models, the different dimensions affect each other sequentially. In the third model, satisfaction affects the three types of loyalty independently. 
The authors reported that this model yielded better results and thus argued that it is the most accurate. The current study views the relationship between customer satisfaction and each level of loyalty in a similar manner.

\section{Conceptual framework and hypotheses}

In this section, the dimensions of loyalty discussed in the literature are defined and research on the influence of customer satisfaction on these dimensions is presented. In order to decide which dimensions should be addressed here, the loyalty literature is also reviewed, with particular attention to the studies by RundleThiele [2005] and Oliver [1997].

\subsection{Attitudinal loyalty}

An individual's attitudinal loyalty is reflected by his psychological tendencies towards a brand [Dick, Basu, 1994]. Rundle-Thiele [2005] associated this type of loyalty with customers' perceptions of purchasing behaviour. Similarly, the current paper defines it as perceiving the action of buying products from the supplier as something feasible and positive.

According to Kim, Vogt, and Knutson [2015], satisfaction positively affects the affective, cognitive, and conative dimensions of loyalty. The authors measured the level of affective loyalty by analysing customers' attitudes towards a brand; in the current study, the concept of attitudinal loyalty is addressed in a similar manner. Kim and Ok [2009] found that regular restaurant customers believe that the benefit they obtain is greater than the cost they incur and thus their affective commitment to the brand increases as a result of their satisfaction. This, in turn, might improve their opinion about it and consequently increase their attitudinal loyalty. The following hypothesis was therefore developed:

H1: Customer satisfaction positively affects attitudinal loyalty.

\subsection{Behavioural loyalty}

Sanchez, Vijande, Gutierrez [2012] usually adopt a behavioural approach and consider such elements as purchasing frequency/ratio/amount, word-of-mouth, and price flexibility. On the other hand, multi-dimensional studies [e.g. RundleThiele, 2005] address behavioural loyalty in a narrower framework, focusing on customer choice. The current paper adopts the understanding of behavioural loyalty proposed by Rundle-Thiele [2005], who analyses the answers to such questions as whether a brand is the customer's first choice or if he considers purchasing products from rival firms. 
Özgüven [2008] contends that customers' satisfaction with physical conditions, security, and comfort of transportation services is closely associated with their company choice. Thus, as their level of satisfaction increases, customers begin to show preference for the company whose services they most frequently use and their behavioural loyalty consequently increases. In their experimental study conducted in the service sector, Bougie, Pieters, and Zeelenberg [2003] found that dissatisfaction with a product experienced by university students results in a decreased preference for the brand and an increased preference for other brands, with anger as a mediator variable. This confirms the existence of a linear correlation between satisfaction and behavioural loyalty. Thus, the following hypothesis was developed:

H2: Customer satisfaction positively affects behavioural loyalty.

\subsection{Price tolerance}

In free market economies, price plays an important role in the reasonable process of purchasing the desired goods or services [Topuz, Çambaşı, 2014]. Willingness to pay a higher price for a certain brand - or, in other words, price tolerance is basically related to the concept of consumer surplus. From the perspective of a reasonable economic behaviour, customers are expected to pay higher prices for products that yield higher satisfaction [Anderson, 1996].

Huber, Herrmann, and Wricke [2001] argued that price was given less attention than it deserves in the customer satisfaction literature and conducted a study in the service sector. They found that when end customers feel satisfied with the service, they are willing to pay higher prices. According to the authors, this is because a satisfied customer wishes to continue his relationship with the brand. Research conducted in the air transport sector [Martín-Consuegra, Molina, Esteban, 2007] and mobile phone sector [Zeng et al., 2011] also indicates that more satisfied customers are more willing to tolerate high prices and price changes. The following hypothesis was therefore developed:

H3: Customer satisfaction positively affects price tolerance.

\subsection{Complaining behaviour}

When consumers experience a problem with a product, they share their complaints about the brand or company with other customers, organisations such as consumer rights associations, the media, and the company itself [Bloemer, Ruyter, Wetzels, 1999; Rundle-Thiele, 2005].

Although some studies show that very few dissatisfied customers tend to resort to complaining behaviour [Tax, Brown, 1998], it seems to be worth to explore 
the relationship between customer satisfaction and complaining behaviour. Customers who decide to share their complaints wish to find solution to their problems or to re-evaluate their relationship with the brand [DeWitt, Nguyen, Marshall, 2008].

According to the model proposed by Singh [1988], when customers experience dissatisfaction with a product, the first thing they do is complain about the brand to the people around them. The author argues that their main motive is to share the disillusionment. They thus tend to persuade other customers not to buy the same product. According to Bougie, Pieters, and Zeelenberg [2003], when customers are dissatisfied with the service, they are likely to demonstrate behaviours such as informing the supplier, requiring the supplier to solve the problem, or notifying consumer rights associations. The authors point out that customer dissatisfaction first leads to anger, which subsequently triggers complaining behaviour. Özer, Ergeneli, Hamidli [2010] conducted a study among Turkish and Azeri consumers and distinguished two types of reactions displayed by dissatisfied consumers: sharing their complaints with the company or with their acquaintances. Thus, as customer satisfaction increases, the risk of complaining behaviour decreases. The following hypothesis was therefore developed:

H4: Customer satisfaction negatively correlates with complaining behaviour.

\subsection{Word-of-mouth}

There is a large number of studies dealing with word-of-mouth as one of the dimensions of loyalty [Bloemer, Ruyter, Wetzels, 1999; Liang, Wang, 2006; Sanchez, Vijande, Gutierrez, 2012]. In the current study, word-of-mouth is understood as one of the discrete dimensions of loyalty and refers to praising and recommending the product to acquaintances [Reichheld, 2003].

Although Auh and Shih [2005] addressed loyalty as a unidimensional construct, they asked about behavioural intention and word-of-mouth while conducting their measurements. According to the authors, as the level of satisfaction with the service increases, so does the likelihood of recommending the service provider to friends or colleagues. Bougie, Pieters, and Zeelenberg [2003] found that when university students do not feel satisfied with the service they received, they tend to inform their friends and acquaintances about it and recommend them not to use the services of the company in question.

There are studies that investigate the relationship between satisfaction and word-of-mouth marketing among Turkish consumers. Studying a land transportation company, Özgüven [2008] found that satisfied customers tend to recommend the company to their friends. In another study, Özer, Ergeneli, and Hamidli [2010] found that Turkish and Azeri consumers tend to persuade their relatives 
and friends not to buy products from a company that dissatisfied them. The following hypothesis was therefore developed:

H5: Customer satisfaction positively affects word-of-mouth marketing.

\subsection{Behavioural intention}

In the literature, behavioural intention plays an important role in defining and measuring loyalty both in approaches that view loyalty as a unidimensional and multi-dimensional construct. In the former case, the term 'repurchase the brand' is used [Hyun, 2010; Lai, 2015]. Studies that treat consumer loyalty as a bidimensional or multi-dimensional construct conceptualise it as an 'intention to repurchase' [Kim, Vogt, Knutson, 2015; Rundle-Thiele, 2005].

The relationship between customer satisfaction and behavioural intention has been investigated in different sectors. In the IT B2B industry, it increases the intention to repurchase [Auh, Shih, 2005]. It was found that customers satisfied with air transport services view themselves as loyal customers and plan to buy tickets from the same company in the future [Martín-Consuegra, Molina, Esteban, 2007]. Löfgren, Witell, and Gustafsson [2008] conducted an empirical study to investigate the effect of different packages on customer perception and found that customer satisfaction positively affects the intention to repurchase. Moreover, it was found that when regular restaurant customers are satisfied with the service, they wish to revisit the same restaurant and the frequency of their visits is not lower than before [Kim, Ok, 2009]. The following hypothesis was therefore developed:

H6: Customer satisfaction positively affects behavioural intention.

\section{Methodology}

In order to test the developed model, a survey was conducted in the electronic security services industry (ESSI). ESSI offers monitoring intended to detect thefts, fires, and other emergencies by using cameras and alarm systems. This industry is characterised by a strong, multi-dimensional relationship between satisfaction and loyalty, which makes it convenient to collect data. Moreover, collecting data from a single industry allows to eliminate deviations that might arise from product differentiation. Electronic security services are provided for residential or commercial customers, but only the latter were the subject of this survey. According to Aksoy, Atilgan, and Akinci [2003], the service industry is more complex than the consumer market and needs to be analysed more extensively. 


\subsection{Data collection}

A questionnaire was elaborated based on previous studies [Bennett, Härtel, McColl-Kennedy, 2005; Bloemer, Ruyter, Wetzels, 1999; Keh, Xie, 2009; RundleThiele, 2005; Zeithaml, Berry, Parasuraman, 1996] and consisted of two parts. The first part includes items for satisfaction and dimensions of loyalty; the second part consists of demographic questions (position of respondent, foundation year of company, number of employees). Dimensions of loyalty were measured using a nineteen-item, five-point Likert type scale: attitudinal loyalty with four items (adapted from Rundle-Thiele [2005]), behavioural loyalty with two items (adapted from Rundle-Thiele [2005]), behavioural intention with three items (adapted from Rundle-Thiele [2005]), price tolerance with three items (adapted from Keh, Xie, 2009; Rundle-Thiele [2005]), word-of-mouth with four items (adapted from Bloemer, Ruyter, Wetzels [1999]; Rundle-Thiele [2005]), and complaining behaviour with three items [Zeithaml, Berry, Parasuraman, 1996). Satisfaction was measured with four items [Bennett, Härtel, McColl-Kennedy, 2005]. All constructs were translated from English into Turkish via a process of double translation.

The data was collected from the customers of electronic security companies operating in Gaziantep - a fast-growing city located in southeastern Turkey that accommodates numerous small and medium-sized enterprises in need of their services. Turkey is a developing country with its own unique dynamics, which is why it is expected to have different characteristics than other economies (US, Europe, Far East, etc.), investigated in previous research. The period covered was July and August 2015. Convenience sampling method was used to reach respondents because of limited time and financial resources. Data was collected in faceto-face interviews conducted by field representatives with owners and partners (82\% of respondents) or managers in charge of electronic security systems (18\% of respondents) in 293 small and medium-sized businesses operating in the automotive, healthcare, retailing, textile, and construction sector. $45 \%$ of them have been using the services of the same company for five years or less and $55 \%$ of them - for more than five years. 87\% of them were are small (0-49 employees) and 13\% medium-sized (50-200 employees) entities.

\subsection{Analysis and findings}

Simple linear regression analysis was performed in order to test the hypotheses after carrying out explorative factor analysis to find whether the dimensions of loyalty can be classified as suggested in literature. KMO test and Bartlett's test of sphericity were used to check the suitability of the data for factor analysis and both were passed. All items measuring loyalty variables had high factor loadings 
except one of the items used for word-of-mouth. After it was excluded, the remaining six factors (attitudinal loyalty, behavioural loyalty, behavioural intention, word-of-mouth, price acceptance, and complaining behaviour) explained the data sufficiently $-72.3 \%$ of the total variance. Then, internal consistency of the variables and the total scale were tested with Cronbach's alpha coefficient. All values were higher than 0.70 and thus acceptable for further research [Nunnally, 1978].

The link between satisfaction and each of the dimensions of loyalty was checked with linear simple regression analysis. Prior to that, Wald-Wolfowitz runs test was used to confirm the randomness hypothesis. Moreover, the kurtosis and skewness values showed that the data have a distribution close to normal [Shao, 2002]. The summary of regression results is presented in Table 1.

Table 1. Regression analysis results for satisfaction and dimensions of loyalty

\begin{tabular}{|l|c|c|c|c|}
\hline \multicolumn{1}{|c|}{ Dependent variable } & $\mathrm{R}^{2}$ & Adjusted $\mathrm{R}^{2}$ & $\beta$ & $\mathrm{p}$ \\
\hline attitudinal loyalty & 0.429 & 0.427 & 0.655 & $0.000^{*}$ \\
\hline behavioural loyalty & 0.020 & 0.017 & 0.142 & $0.015^{* *}$ \\
\hline price tolerance & 0.144 & 0.141 & 0.380 & $0.000^{*}$ \\
\hline complaining behaviour & 0.009 & 0.006 & -0.096 & 0.103 \\
\hline word-of-mouth & 0.436 & 0.434 & 0.660 & $0.000^{*}$ \\
\hline behavioural intention & 0.556 & 0.555 & 0.746 & $0.000^{*}$ \\
\hline
\end{tabular}

Notes: ${ }^{*} \mathrm{p}<0.001 ;{ }^{* *} \mathrm{p}<0.05$; independent variable: satisfaction.

Source: Own elaboration.

According to the results, satisfaction has a significant contribution to the prediction of attitudinal loyalty $(\beta=0.655, \mathrm{p}<0.001)$, price tolerance $(\beta=0.380$, $\mathrm{p}<0.001)$, behavioural loyalty $(\beta=0.142, \mathrm{p}<0.05)$, behavioural intention $(\beta=0.746$, $\mathrm{p}<0.001)$, and word-of-mouth $(\beta=0.660, \mathrm{p}>0.001)$. On the other hand, no significant relation was found between satisfaction and complaining behaviour $(p<0.05)$. Satisfaction has the strongest relationship with behavioural intention, and the weakest with behavioural loyalty. The findings therefore confirmed H1, $\mathrm{H} 2, \mathrm{H} 3, \mathrm{H} 5$, and H6, but not $\mathrm{H} 4$.

\section{Conclusions}

The proposed framework provides a better understanding of the role of satisfaction in the formation of loyalty. The current study intended to develop a more holistic approach to the relationship between satisfaction and the dimensions of 
loyalty. Moreover, the obtained findings are expected to help marketing practitioners to more effectively allocate their resources. In fact, the authors found that in the B2B service industry satisfaction affects particular dimensions of loyalty at varying degrees, which means that investments made to enhance customer satisfaction have different influence on different dimensions of loyalty. Therefore, to influence the dimensions slightly affected (behavioural loyalty) or not affected (complaining behaviour) by customer satisfaction, other factors should be targeted.

Behavioural intention, attitudinal loyalty, and word-of-mouth were found to be relatively highly affected by satisfaction. Traditional research explored mostly these three (or just two) dimensions. The current study shows that, in addition to these dimensions, satisfaction has a considerable influence on price tolerance and weak influence on behavioural loyalty, which clearly demonstrates the multidimensionality of loyalty in the B2B service industry.

The variable most strongly affected by satisfaction is behavioural intention, which refers to the respondents' propensity to make purchases from the given company. Hence, it can be argued that satisfaction has a particularly considerable influence on the intention to repurchase. This concurs with the findings for a different industries reported by Auh and Shih [2005], Martín-Consuegra, Molina, and Esteban [2007], as well as Kim and Ok [2009], which therefore seem generalisable to the whole service industry.

Satisfaction makes a significant contribution to the prediction of attitudinal loyalty and behavioural loyalty (here, however, the link is weaker). This means that satisfaction strongly affects customer's attitude towards a brand, but not his preference for it as his first choice. This fact should be taken into account when developing a competition strategy and alternative ways of gaining advantage over rivals should be devised.

A negative relationship was expected between satisfaction and complaining behaviour, but no relationship was found. It is possible that it is affected by another variable. Bougie, Pieters, and Zeelenberg [2003] argue that dissatisfaction affects complaining behaviour by means of anger as a mediating variable. Further research should take this fact into consideration when exploring complaining behaviour.

The data analysed in the current study concern a single service. This makes it difficult to generalise the findings to all services offered in the B2B sector. Therefore, it is recommended to carry out similar research in other sectors. Another limitation of the current study is its sample, comprised of businesses operating in the city of Gaziantep, which makes it impossible to generalise the findings to the Turkish market. On the other hand, the majority of the studies reported in the literature were conducted in developed countries or emerging markets. Further studies, particularly in low-income countries from different 
parts of the world, might make important contributions to the understanding of the effect of various economic and cultural variables on the relationship between satisfaction and different dimensions of loyalty.

\section{References}

Aksoy S., Atılgan E., Akınc1 S., 2003, Airline services marketing by domestic and foreign firms: Differences from the customers' viewpoint, Journal of Air Transport Management, no 6.

Amine A., 1998, Consumers' true brand loyalty: The central role of commitment, Journal of Strategic Marketing, no. 4.

Anderson E.W., 1996, Customer satisfaction and price tolerance, Marketing Letters, no. 3.

Auh S., Shih C., 2005, The relative effects of relationship quality and exchange satisfaction on consumer loyalty, Journal of Business-to-Business Marketing, no. 2.

Bennett R., Härtel C.E.J., McColl-Kennedy J.R., 2005, Experience as a moderator of involvement and satisfaction on brand loyalty in a business-to-business setting 02-314R, Industrial Marketing Management, no. 1.

Bloemer J., de Ruyter K., Wetzels M., 1999, Linking perceived service quality and service loyalty: A multi-dimensional perspective, European Journal of Marketing, no. 11/12.

Bougie R., Pieters R., Zeelenberg M., 2003, Angry customers don't come back - they get back: The experience and behavioral implications of anger and dissatisfaction in services, Journal of the Academy of Marketing Science, no. 4.

Brennan D.R., Turnbull P.W., Wilson D.T., 2003, Dyadic adaptation in business-to-business markets, European Journal of Marketing, no. 11/12.

DeWitt T., Nguyen D.T., Marshall R., 2008, Exploring customer loyalty following service recovery: The mediating effects of trust and emotions, Journal of Service Research, no. 3.

Dick A.S., Basu K., 1994, Customer loyalty: Toward an integrated conceptual framework, Journal of the Academy of Marketing Science, no. 22.

Eggert A., Ulaga W., 2002, Customer perceived value: A substitute for satisfaction in business markets? Journal of Business and Industrial Marketing, no. 2/3.

Fiol L.J.F., Alcaniz E.B., Tena M.A.M., Garcia J.S., 2009, Customer loyalty in clusters: Perceived value and satisfaction as antecedents, Journal of Business-to-Business Marketing, no. 16.

Frazier G.L., Gill J.D., Kale S.H., 1989, Dealer dependence levels and reciprocal actions in a channel of distribution in a developing country, Journal of Marketing, no. 53.

Grönholdt L., Martensen A., Kristensen K., 2000, The relationship between customer satisfaction and loyalty: Cross-industry differences, Total Quality Management, no. 11.

Homburg C., Koschate N., Hoyer W.D., 2005, Do satisfied customers really pay more? A study of the relationship between customer satisfaction and willingness to pay, Journal of Marketing, no. 69 .

Huber F., Herrmann A., Wricke M., 2001, Customer satisfaction as an antecedent of price acceptance: Results of an empirical study, Journal of Product \& Brand Management, no. 3.

Hyun S.S., 2010, Predictors of relationship quality and loyalty in the chain restaurant industry, Cornell Hospitality Quarterly, no. 2.

Keh H.T., Xie Y., 2009, Corporate reputation and customer behavioral intentions: The roles of trust, identification and commitment, Industrial Marketing Management, no. 7.

Kim M., Vogt C.A., Knutson B.J., 2015, Relationships among customer satisfaction, delight, and loyalty in the hospitality industry, Journal of Hospitality \& Tourism Research, no. 2. 
Kim W., Ok C., 2009, The effects of relational benefits on customers' perception of favorable inequity, affective commitment, and repurchase intention in full-service restaurants, Journal of Hospitality \& Tourism Research, no. 2.

Lai I.K.W., 2015, The roles of value, satisfaction, and commitment in the effect of service quality on customer loyalty in Hong Kong-style tea restaurants, Cornell Hospitality Quarterly, no. 1.

Lee Y.W., Bellman S., 2008, An augmented model of customer loyalty for organizational purchasing of financial services, Journal of Business-to-Business Marketing, no. 3.

Löfgren M., Witell L., Gustafsson A., 2008, Customer satisfaction in the first and second moments of truth, Journal of Product \& Brand Management, no. 7.

Liang C.J., Wang W.H., 2006, The behavioural sequence of the financial services industry in Taiwan: Service quality, relationship quality and behavioural loyalty, The Service Industries Journal, no. 2.

Martín-Consuegra D., Molina A., Esteban Á., 2007, An integrated model of price, satisfaction and loyalty: An empirical analysis in the service sector, Journal of Product \& Brand Management, no. 7.

Mattila A., Wirtz J., 2000, The role of preconsumption affect in postpurchase evaluation of services, Psychology and Marketing, no. 7.

McMullan R., 2005, A multiple-item scale for measuring customer loyalty development, Journal of Services Marketing, no. 7.

Nijssen E., Singh J., Sirdeshmunkh D., Holzmüeller H., 2003, Investigating industry context effects in consumer-firm relationships: Preliminary results from a dispositional approach, Journal of the Academy of Marketing Science, no. 1.

Nunnally J.C., 1978, Psychometric theory, McGraw-Hill, New York.

Oliver R.L., 1980, A cognitive model of the antecedents and consequences of satisfaction decisions, Journal of Marketing Research, no. 17.

Oliver R.L., 1997, Satisfaction: A behavioral perspective on the consumer, McGraw-Hill, New York

Özdemir M., Koçak A., 2002, İlişkisel pazarlama çerçevesinde marka sadakatinin oluşumu, Ankara Üniversitesi SBF Dergisi, no. 2.

Özer L., Ergeneli A., Hamidli V., 2010, Satınalma sonrası tatminsizlik durumundaki tepkiler: Türkiye ve Azerbaycan'da bir araștirma, Anatolia: Turizm Araştırmaları Dergisi, no. 1.

Özgüven N., 2008, Hizmet pazarlamasında müşteri memnuniyeti ve ulaştırma sektörü üzerinde bir uygulama, Ege Akademik Bakış, no. 2.

Reichheld F.F., 1993, Loyalty and the renaissance of marketing, Marketing Management, no. 4.

Reichheld F.F., 1996, The loyalty effect: The hidden force behind growth, profits, and lasting value, Harvard Business School Press, Boston.

Reichheld F.F., 2003, The one number you need to grow, Harvard Business Review, no. 6.

Rossomme J., 2003, Customer satisfaction measurement in a business-to-business context: A conceptual framework, The Journal of Business \& Industrial Marketing, no. 2/3.

Rundle-Thiele S., 2005, Exploring loyal qualities: Assessing survey-based loyalty measures, Journal of Services Marketing, no. 7.

Rundle-Thiele S., Mackay M.M., 2001, Assessing the performance of brand loyalty measures, Journal of Services Marketing, no. 7.

Sanchez J.A.L., Vijande M.L.S., Gutierrez J.A.T., 2012, Value-creating functions, satisfaction and loyalty, Quality and Quantity, no. 46. 
Shao A.T., 2002, Marketing research: An aid to decision making, Cincinnati, Thomson-Southwestern.

Singh J., 1988, Consumer complaint intentions and behavior: Definitional and taxonomical issues, Journal of Marketing, no. 52.

Spreng R.A., Shi L.H., Page T.J., 2009, Service quality and satisfaction in business-to-business services, Journal of Business \& Industrial Marketing, no. 8.

Tax S.S., Brown S.W., 1998, Recovering and learning from service failure, Sloan Management Review, no. 1.

Topuz Y.V., Çambaşı İ., 2014, Asgari ücretli tüketicilerin fiyat ve fiyat-kalite algısı: cep telefonu ürünleri üzerine bir araştırma, Niğde Üniversitesi IIIBF Dergisi, no. 1.

Wirtz J., Mattila A.S., Tan R.L.P., 2000, The moderating role of target-arousal on the impact of affect on satisfaction: An examination in the context of service experiences, Journal of Retailing, no. 3.

Yi Y., La S., 2004, What influences the relationship between customer satisfaction and repurchase, Psychology \& Marketing, no. 21.

Zeithaml V.A., Berry L.L., Parasuraman A., 1996, The behavioral consequences of service quality, Journal of Marketing, no. 60.

Zeng F., Yang Z., Li Y., Fam K., 2011, Small business industrial buyers' price sensitivity: Do service quality dimensions matter in business markets? Industrial Marketing Management, no. 3.

Taner Sigindi ( epostam@yahoo.com

Muğla Sitkı Koçman University, Faculty of Economics and Administrative Sciences, 48000 Kötekli Campus, Mugla, Turkey 